\title{
Marianne van der Heijden (1922-1998)
}

Citation for published version (APA):

Netel, E. J. (2017). Marianne van der Heijden (1922-1998): het archief als bron van (kunst)historische herinnering. [, Maastricht University]. Datawyse / Universitaire Pers Maastricht. https://doi.org/10.26481/dis.20171108en

Document status and date:

Published: 01/01/2017

DOI:

10.26481/dis.20171108en

Document Version:

Publisher's PDF, also known as Version of record

\section{Please check the document version of this publication:}

- A submitted manuscript is the version of the article upon submission and before peer-review. There can be important differences between the submitted version and the official published version of record.

People interested in the research are advised to contact the author for the final version of the publication, or visit the DOI to the publisher's website.

- The final author version and the galley proof are versions of the publication after peer review.

- The final published version features the final layout of the paper including the volume, issue and page numbers.

Link to publication

\footnotetext{
General rights rights.

- You may freely distribute the URL identifying the publication in the public portal. please follow below link for the End User Agreement:

www.umlib.nl/taverne-license

Take down policy

If you believe that this document breaches copyright please contact us at:

repository@maastrichtuniversity.nl

providing details and we will investigate your claim.
}

Copyright and moral rights for the publications made accessible in the public portal are retained by the authors and/or other copyright owners and it is a condition of accessing publications that users recognise and abide by the legal requirements associated with these

- Users may download and print one copy of any publication from the public portal for the purpose of private study or research.

- You may not further distribute the material or use it for any profit-making activity or commercial gain

If the publication is distributed under the terms of Article $25 \mathrm{fa}$ of the Dutch Copyright Act, indicated by the "Taverne" license above, 


\section{English summary}

Marianne van der Heijden (1922-1998)

The archive as a source of (art)historical memory 

Scattered in hidden attics lies many a legacy of an artist whose place in the national canon of art is unclear. During their lives these artists were active in the world of art, but at the time of their death, assessment of their work no longer takes place within that world of art but within the discipline of art history. The decision whether or not the artist will occupy a place in the history of art is in most cases prepared by museum directors, curators and collectors. When posthumous work ends up in a museum, the objects are given a registration number and become by that very fact institutionalized. This institutionalization process usually takes place unobtrusively. The selection of who is, and who is not included in the collection is performed internally and often the visibility that the artist had within the art circuit when alive, is then used as a guide.

However, the current research into the legacy of an unknown artist shows that legacies of artists who have played no prominent role in the world of contemporary art can still be of considerable importance to the Dutch heritage. An important principle here is that a collection of artworks is not only of value to the art world as such, but also has a more general, cultural and historical value. Especially when these works are supplemented with documents that provide insight into the creative process, they can provide understanding of the exclusion mechanisms by which such an artist has not made its way into the canon. In this way studying the legacies gives insight into the criteria on which the canon of art is ultimately based.

\section{Marianne van der Heijden}

Marianne van der Heijden (1922-1998) was active as an artist in Limburg since the 1950-ies until her death. Her legacy thus covers the second half of the previous century. It is striking that, despite the quality of her work, she has gone largely unnoticed in the summary book of the postwar Dutch art. She is even missing from the list of Flemish and Dutch women artists in the catalog of the exhibition "Elck zijn waerom. V rouwelijke kunstenaars in België en Nederland 1500-1950 " (1999), while her peers Lotti van der Gaag (1922-1999) and the slightly younger Odette Collon (1926) are included.

I became acquainted with the legacy of Van der Heijden in 2002 when I worked as a curator at the "Museum Henriette Polak" in Zutphen. At that time, the work of Marianne van der Heijden could not be included in the collection because it did not fit into the museum's policy that was focused around the work of Joop Sjollema and his friends, the founders of the museum. Still, I was curious about the work of this female artist, which I was not familiar with. When I saw her legacy, I became even more curious because it was not only very large but also very diverse and it showed a high professional standard.

Van der Heijden's legacy consists of more than 3,000 artworks, including graphics, paintings behind glass, mosaic, material art, paper collages, pastels and designs for different monumental wall works. In addition it includes diaries and letters. A special place in the collection is taken up by the correspondence between her and the Father- 
Carmelite Bruno Borchert (1923-1994). How could it be that this talented artist is absent in any survey of Dutch art? And why did she keep the correspondence between her and the Father-Carmelite available for future researchers? After I had the opportunity in 2013 for Museum van Bommel van Dam in Venlo to prepare an exhibition and publication about her, I decided to try and find answers to these questions. The surviving diaries, letters, travel journals and photos soon appeared to be the key to finding these answers.

\section{Feminist art history}

The question of why women are not represented in the surveys of art was one of the first questions addressed by feminist art history which started as a discipline in the early seventies. The American art historian Linda Nochlin publicly put forward the question "Why have there been no great women artists?". Her article in Art Forum in 1970 was the beginning of a feminist history of art. It marked the start of the retrieval of women artists and exposed the premises of the institution of art that had brought to scale discrimination against women. Ubiquitous views on masculinity and femininity prevented women to move around freely in society and devote themselves seriously to art. Their sculpture, painting, drawing or embroidery was just accepted as homely pastime or hobby. Nochlin made it clear that the history of art had been blind to the exclusion of women.

This situation made it important for her to reveal and break through the romantic, elitist, individual-based structure on which art historical practice was based. Germaine Greer made a further significant contribution in filling the gap of female artists in the canon by her book The Obstacle Race (1979). She rescued a large number of artists from oblivion and formulated the sociological, psychological and cultural conditions and attitudes that often prevented women artists to make progress and obtain a place in the official history or world of art. The English art historians Rozsika Parker and Griselda Pollock also criticized art historical scholarship, which they described in Old Mistresses, Women, Art and Ideology (1981) as an oppressive medium. They felt that the history of art had to be fundamentally deconstructed and proposed as a central focus of research the cause of the denial of the existence of female artists. They stated that producing biographies was not the appropriate method here, because in their eyes this involved too little attention for the material works of the female artists.

\section{Traditional art-historical monography falling from grace}

To investigate the oeuvre of an artist the monograph is the standard art-historical practice. Since the eighties of the last century this approach has fallen out of favor. In his article "That Obscure Object of Desire: The Art of Art History" (1989), art historian 
Donald Preziosi puts forward the arguments for the disappearance of this popular item in the history of art. Central to the rejection is his realization that the monographs often constructed myths about artists as geniuses who produced series of masterworks. This was based on the romantic notion of the artist as a single homogeneous entity, whose work was to be placed in the historical context of a given period and country of origin or residence of the artist. Art was thus often reduced to just that context.

Another reason why Preziosi rejects the monographic approach is that the art historian in the process of writing behaves like a connoisseur and revealer who alone possesses the extraordinary ability to discover the genius of the artist. Moreover, he is able to position the artists in a logically constructed pyramid of good and bad art according to strict aesthetic standards. The standards used by the monographer, however, are open to question because they always depend on time-bound institutions, social classes and ideologies. The statements of such a monographer are therefore arbitrary according to Preziosi.

Partly by the dislike of the monographic approach within the discipline of art history, the attention of art history researchers shifted to work-immanent analysis and the reception history of autonomous works of art. Writing life stories and fitting the works of art inside these was left to authors outside the academic world. With this development the scientific discussions on the content of these monographs unfortunately also disappeared to the background.

In this study of a single, complete legacy I want to advocate with new arguments the importance of biographical research. The thoughts, dilemmas, experiences, feelings and ideas which an artist has entrusted to his or her diary or intimate letters provide insight into the complex process by which the artist has been included or excluded into the canon. I agree with Geertje Maks conjecture that studying these private matters is precisely what is of interest in providing a more nuanced view of the history (of art). (Mak, 2007).

It is however of paramount importance that the potential pitfalls in writing biographical studies, such as exposed by the feminist art historians Parker and Pollock and later Donald Preziosi, are to be avoided. So, I am not going to put forward Marianne van der Heijden as a lost genius, whose talents have remained unfairly not noticed. Instead, I will take her practice of art as a model for the inclusion and exclusion mechanisms that have led to the existing description of the canon of Dutch post-war art. I use the information from her diaries and in particular the mutually surviving correspondence between her and Father-Carmelite Bruno Borchert. These documents provide a unique insight into the daily practice of the artist: the books she read, the shows she attended and the discussions she had with family and friends. Her personal archive (Archive Marianne van der Heijden, collection Museum van Bommel van Dam) is therefore the ideal place to find answers to the question why her fame never reached further than South Limburg, the region where she lived and worked. 


\section{The function of the archive following Jacques Derrida}

For understanding the function of an archive I found Jacques Derrida's Archive Fever (1995) particularly helpful. In his book he makes it clear that an archive is not just an immovable black box in which documents or objects are stored, but that these elements always contain promises for the future. Each element of archive, however small or unobtrusive, has the potential to generate new ideas for future researchers.

During the archival research there is always a rearrangement of the records. In each new investigation, with a new question, new and different documents become important. Derrida suggests that because of this process the actual person who created the archive can never be reproduced in its fullness by biographical research. Moreover, what the biographer writes can never be conclusively true. His or her argument is always a reinterpretation, or retelling of what was originally written in the documents. Derrida says, that, although the researcher attempts to resurrect the creator, he or she rather creates a phantom image of its protagonist and the original person can never been brought back to life.

In my study I follow Derrida's ideas and it is thus not my intention to resurrect Marianne van der Heijden in her fullness and "final truth". In her legacy, I will look for the traces she has left as a creator to show to what fascinating and complex stories following these traces may lead. Van der Heijden has read all the documents before her death and in some cases has put comments in the margins, but she has also cut out specific names from the handwritten texts.

On the basis of these traces I want resurrect her voice and reveal the dilemmas she faced in as a female artist. In addition, by taking the recommendations of Preziosi and the feminists Parker and Pollock seriously, I will put Van der Heijden's works of art at the forefront, so that I do not fall into the trap of producing another much-maligned genius-glorifying monograph.

\section{Intersections in the life and work of Marianne van der Heijden}

To avoid a linear discussion of the artist and her biography, I have set up my thesis around the intersections of the life and work of my protagonist. The intersections I extracted are: 1951, 1962, 1970, 1987 and 1998. I take as starting point the year 1951, because that was the year when the career of Marianne van der Heijden took off. After completion of her training at the Amsterdam State Academy of Fine Arts and participation in the Prix de Rome, Van der Heijden chose to return to her birthplace. On her return, she could start to work immediately on several commissions from various churches. I chose deliberately not to take the birthdate of Marianne as the starting point, because not her life but her work is central in my analysis.

As the second intersection, I consider the year 1962, in which I explore what has materialized of her career, a decade after her ambitious start as an artist. The year 1962 
is also of interest because her correspondence with Father Bruno Borchert intensified. This correspondence provides insight into how the artist, as a woman of forty in the beginning of the sixties, stood in life.

In 1970 her career is on a low. Van der Heijden makes little art and the correspondence with Father Bruno has come to an end. Her work comes back to life during the seventies, but by then she has finally left behind the ecclesiastical art commissions. Next I take 1987 as the fourth intersection. This is the year in which she turns 65. I explore how Van der Heijden perceives life at that age. Her artist's life abruptly ends in 1998, when she commits suicide by taking an overdose of sleeping pills. What brought her to this rigorous final step and was the choice for it in any way related to the obstacles she encountered as an artist?

As an introduction to every intersection I present a work of art or document that serves as a prelude to the content of the chapter. These are the artifacts I selected from the legacy and that are, again and again, the fuel for a re-interpretation of her work. At the beginning of each chapter, I also include a photo of the artist taken in the same year year. These portraits show how the work may have been produced by the same name, but not necessarily by the same person.

\section{Excluded from the canon}

The diversity of her work immediately becomes apparent, once we put the works that Van der Heijden made in 1951, 1962, 1970, 1987 and 1998 in a series. She painted with gouache paint, made woodcuts, drew with reed pen and Indian ink and worked with pastel. We can add to this the techniques that she chose for her monumental work, sgraffito, stained glass and mosaic as well as her experiments with used objects. Her oeuvre cannot be described consistently: there is no single, overall way to describe the work of Marianne van der Heijden. Were we to build a structure of her work as a logical sequence of works, such a structure would have little correspondence to the unpredictable reality of her practice. The artist was not looking for a personal signature, nor was it her intention to join some movement of art.

Germaine Greer identified the absence of a consistent body of work as one of the main reasons why women have not reached the canon. However, when we compare the oeuvre of Van der Heijden to male contemporaries, it appears that many of them also were not working consistently. The works of Lex Horn (1916-1968), Wally Elenbaas (1912-2008) and Jef Diederen (1920-2009) have also acquired no position in the canon of Dutch art. Marianne van der Heijden concentrated predominantly on monumental art and graphics. These forms of art were awarded little attention in the surveys of Dutch art, regardless of whether the art was created by men or women. Her exclusion from the canon therefore, appears at first glance to have nothing to do with the fact that she is a woman. 
Yet it is noteworthy that no single woman is included in the survey book De Nederlandse identiteit in de kunst na 1945 (1984) with a short biography. The book contains works from only four female artists: Pearl Perlmutter (1915-2008), Ansuya Blom (1956), Marlène Dumas (1953) and Sandra Derks (1960). Of these four, only Perlmutter is of the generation of Van der Heijden. This suggests that there exists little attention for the female artists of Van der Heijden's generation. The life and work of female artists of that generation is such unexplored territory that further research is urgently required.

Until the mid-seventies Marianne van der Heijden worked mainly on commissions for the church. Her most prestigious assignments are: a nine-meter high sgraffito of the risen Christ in the Church of St. Peter and Paul in Eschweiler (1952) and the marble mosaics of the apse and triumphal arch in the private chapel of the Jesuits in Maastricht (1954-1958), now the auditorium of the School of Business and Economics of Maastricht University. Because art historians generally characterize such contracts as applied art, they are not included in the surveys of the Dutch art.

The early sixties were the years in which the artist devoted herself to making stained-glass windows. She worked on two major projects: windows for St. Lambertus Kerkrade and the Fatima Church in Brunssum. Art historians assessed both assignments not on their artistic merits but on the grounds of their religiosity. For the artist, however, the designs for the church in Brunssum provided a first step towards abstraction, a direction she further wanted to explore in her free work.

The exploration into abstract art was executed largely in secret and she did not show the results in public. For this reason Van der Heijden is always described as creator of "religious art" and that label has stuck to her ever since. Even Willem K. Coumans, in his monograph of van der Heijden of 1990, puts particular emphasis on the religious or spiritual power of her art. Precisely this aspect received little appreciation from the critics of the national newspapers and magazines. The qualifier "religious art" was a sufficient reason to keep Van der Heijden's work outside the surveys of autonomous Dutch art.

Because Marianne van der Heijden lived and worked in the south of the country she has always been considered a regional artist of Limburg. Here she was appreciated widely and therefore included in the surveys of Limburg art. However, the artist saw herself as anything but a regional person: her mother was German, her father from Brabant, she did not speak the regional dialect and preferably joined people from outside the region.

\section{Nowhere to belong to}

Marianne van der Heijden identified herself neither with Limburg artists nor with any group within the cultural sector. She commended herself as an outsider who far from the public arena practiced her art according to her own insights. The attitude of an 
outsider made Van der Heijden elusive and has helped to ensure that she remained largely invisible in Dutch art. But her fear of commitment also caused her loosing sight of what she wanted to do and who she was.

At the beginning of her career her creed was: as long as I do my best, everything will turn out to be fine. In those years she acted rather pliable with respect to the wishes of her parents and religious clients. In the sixties she breaks loose of these ties and gets engaged in a clandestine relationship with Father Bruno Borchert. Through him she achieves that the magazine Speling, of which he was the editor, virtually always published her work uncritically and faithfully. But, through this medium, which focused on spirituality, she does not manage to get the attention of national critics of art and directors of art museums outside Limburg.

During her career Van der Heijden knows no role models that would help shaping her artistry. In her family and social environment no women existed who were able to establish an autonomous career independent of the church. The introduction to the work of Paula Modersohn-Becker (1876-1907) at the end of the forties in the Stedelijk Museum Amsterdam was therefore particularly inspiring. Modersohn-Becker was the first painter who showed the female nude from the perspective of women. She presented it in an unusual way as a goddess, with Christian symbolism reflective of both Mary and the suffering Christ. That special iconography attracted Van der Heijden and led her to experiment with fragile, nude self-portraits with Indian ink in the evenings, while during the day she worked on the apsis mosaics of the Jesuit chapel. Like Modersohn-Becker Van der Heijden chooses to be an artist. To achieve that life she brings the sacrifice of celibacy and thus forgoes motherhood. However, the choice for art and independent living is for Van der Heijden no reason to follow the feminists in the sixties in their fight for independence. Instead, she becomes more and more entangled in the issues of Father Bruno Borchert. When his monastery in Merkelbeek is gradually closed after 1968 he is looking for a home in Maastricht. Ultimately, he is allowed to live on the ground floor of the home that Van der Heijden bought in 1972 at the Papenweg in Maastricht. From that moment on she retreats regularly to her studio and focuses on making free work. At the same time she starts to set up her own collection and brings together her personal documents. It would appear that Van der Heijden consciously brought together and documented her work for the future. A small, inconspicuous note that I found in her last diary reinforces this suspicion. Marianne addresses Maria Straathof, whom she had appointed as executor. She writes: "We [Borchert and Van der Heijden] are very vulnerable in our letters, very old, very fussy and yet again innovating: forward, but only on our own compass. I give them to you personally. Also read my diaries and calendars. They should never get into the wrong hands." (Letter z.d., [1998]). Her diaries and letters contain various secret events, thoughts and dreams, such as a secret marriage proposal of a certain Johny from Surinam, whom she had met in the jazz club Casablanca on the Amsterdam Zeedijk. She did not accept, but it was one more incentive for her to go to work in he countryside of France for the month of September 1950. 
Even greater was her secret regarding the complex relationship with Father Bruno Borchert. Nobody knew - not even her close family and dearest friends - that she offered him shelter when the monastery in Merkelbeek was closing down. She taught him how to live in the secular society, but could not tell anyone because it would then become apparent that they lived in cohabitation. This was, unacceptable to the Catholic community and it would cause disrespect to her family and even more so, harm her name and reputation as an artist of religious commissions.

It is within this this context, that her identity crisis at the end of the sixties becomes more understandable. With it, also her statement "Ik zou zo graag een zwerver willen zijn" (1970) ("I should like to be a wanderer") appears in a different light. Given this turbulent period, full of secrets and lies, she can no longer live uninhibitedly. It is difficult for her to imagine an integral place in society. She sees herself increasingly in the role of outsider in the art, but now also in society. Her choice to live for art meant that cracks were now appearing in her unshakable belief in Catholicism, first as an institution, later as a religion.

Because I could use the diaries and her letters to Borchert in my research, I could make it clear that although Marianne van der Heijden could develop materially as an independent artist, this development turned out to be much more difficult to manage mentally.

\section{The voice of the author}

This study of the legacy of Marianne van der Heijden can only lift a corner of the veil. It suggests that there is much more to discovered when we study scientifically the attics containing posthumous work by artists who do not belong to the canon. I have shown that the jottings, diaries and letters left by the artist, provide important information about the circumstances in which a work of art arose. Through these texts of the artist, he or she posthumously suggests clues to the researcher that could lead to new discoveries and the surviving voice of Marianne van der Heijden, hidden in her posthumous texts, talks about the complicated circumstances in which women had to work since 1945 when they were aiming to become an artist. 